\title{
Amor, justiça e perdão na obra de Paul Ricoeur: Relações Internacionais.
}

Love, justice and forgiveness in the work of Paul Ricoeur: International Relations.

\author{
Norma Caldas Barros Monte Guimarães ${ }^{1}$
}

Este resumo trata dos conceitos de amor, justiça e perdão na obra do expoente da filosofia do século XX:o francês Paul Ricoeur, e sua visão para resolução de conflitos em Relações Internacionais. Um dado marcante da sua trajetória foi a parceria quando jovem com Gabriel Marcel, outro filósofo que valoriza a pessoa humana, o amor e o respeito, tendo sido uma influência primordial para o trabalho posterior de Ricoeur em Amour et Justice. Constança Marcondes César (2012) considera-o mestre do diálogo, dono de uma espantosa erudição, e fez surgir, através de seus escritos, um fio condutor que nos indica, no labirinto dos conflitos das interpretações do homem e do mundo, presentes da filosofia atual, a possibilidade de um horizonte mais aberto, superador das crises em que estamos mergulhados. Mesmo ao sofrer muitas perdas em idade prematura, sempre prosseguiu com esperança e ideia de agir "ensemble" - juntos-, não só comandar, mas participar. Essa é uma visão atual do contexto e cenário internacional, principalmente na vertente da Teoria Idealista das Relações Internacionais, em que a cooperação é a grande forma de atuação. No seu livro Amouret Justice, Paul Ricoeur nos fala da superação de conflitos através da dialética: "l'exercice de la justice n'est pás simplement um cas d'arguments, mais de prise de décision." e "la justice s'oppose à

1 Graduanda em Relações Internacionais pela Universidade Federal do Rio de Janeiro, normacaldasbmg@gmail.com,resumo fruto parcial do projeto de iniciação científico PIBIC/CNPQ/voluntário sob a coordenação da Profa Dra. Constança Marcondes Cesar da Universidade Federal de Sergipe. Resumo também publicado no evento III Colóquio Nacional de Ética e Filosofia Política: Filosofia Política e Relações Internacionais 
l'amour par destraits bien marqués qui vont nous conduire au seuil de notre deuxième partie consacrée à ladialectique de l'amour et de la justice. ${ }^{2}$ Então "deixa de responder apenas às ideias de punição e de reparação, mas se amplia envolvendo a exigência de uma gestão socializada do risco e vinculando-se à ideia de solidariedade em relação à humanidade com um todo".

No campo das Relações Internacionais segundo Cristina Pecequilo (2008, p.144) o idealismo se propõe a apresentar formas de organizar o cenário numa realidade de laços entre os Estados que levará à obtenção da prosperidade individual de cada um e do bem universal e comum do sistema, eliminando a guerra como instrumento de política internacional.Como na dita corrente, Ricoeur acredita na solidariedade e cooperação como meio de convivência da humanidade e Estados. Dá responsabilidade também à geração atual para a manutenção da vida humana sobre a terra, um dos objetivos do internacionalista idealista que deverá ter prudência nas suas ações.

O pensamento de Paul Ricoeur ligado à Justiça tem pontos de aproximação com o pensamento do filósofo político John Rawls, apesar das críticas de Ricoeur a Rawls, uma vez que a noção de equidade , apoiada na tradição antiga, serve de ponto focal das teorias de ambos:

Uma concepção do bem é utilizada para defender a teoria da justiça como equidade contra diversas objeções; (...) Mas se tivermos em conta outras questões, uma análise mais do bem é essencial. Assim a definição dos atos altruístas e superogatórios depende de tal teoria (teoria mais ampla do bem).(RAWLS, 1971, p. 306/307).

O papel do amor e do perdão para se atingir a Justiça na teoria de Paul Ricoeur está em que ele formula a base do seu pensamento em valores morais, como amor e perdão, e juízo de valores superiores para se atingir quando conflitos existirem, para se sobrepor à lei. Neste ponto existe a congruência com a teoria mais ampla do bem de Rawls, quando este nos remete a atos altruístas. O

\footnotetext{
2 “O exercício da justiça não é simplesmente um caso de argumentos, mas de tomada de decisão. A justiça se opõe ao amor pelos traços bem marcados que vão nos conduzir ao cerne da segunda parte consagrada à dialética do amor e da justiça.” Tradução livre pela autora
} 
amor e o perdão são bases morais e psicológicas universais (consciência moral coletiva) que dificilmente traria injustiça, para uma sociedade ordenada e estável ${ }^{3}$.

Com a pesquisa, todo o referencial teórico da filosofia e do pensamento do filósofo Paul Ricoeur se sedimentou principalmente na categoria de Justiça.Vislumbra-se então na Teoria Idealista os fundamentos teóricos semelhantes aos dele para superação de conflitos onde são usados amor e perdão como valores acima da lei para atingir uma "verdadeira" justiça no seio de uma sociedade ordenada e estável.

Publicado no dia 24/10/2014

Recebido no dia 08/10/2014

Aprovado no dia 09/10/2014

\footnotetext{
${ }^{3}$ Para Rawlsa sociedade bem ordenada é aquela concebida para promover o bem dos seus membros e que é regulada
} de forma efectiva por uma concepção pública da Justiça. Teoria da Justiça como equidade. Op. Cit.P. 346 